\title{
PFI建設プロジェクトでの地下リスク評価及び 分担に関する研究
}

\author{
大津宏康 1 尾ノ井芳樹 $2 \cdot$ 大本俊彦 $3 \cdot$ 大西有三 4 ・西山哲 $5 \cdot$ 黄瀬周作 6 \\ 1正会員 博士（工学） 京都大学大学院 助教授 工学研究科（广606-8501 京都市左京区吉田本町） \\ 2正会員 工学士 電源開発株式会社 新事業戦略室（广104-8165 東京都中央区銀座六丁目15-1） \\ 3正会員 博士（工学） MSc.（建設法/仲裁） 英国・米国仲裁士（广182-0023 調布市染地2-8-3） \\ 4正会員 工博 Ph.D. 京都大学大学院 教授 工学研究科（广606-8501 京都市左京区吉田本町） \\ 5 正会員 工修 京都大学大学院 助手 工学研究科 (T606-8501 京都市左京区吉田本町) \\ 6正会員 工学士 淺沼組 土木部（广543-8688 大阪市天王寺区高津町12-6）
}

\begin{abstract}
本研究の目的は, 民間資本活用方式（PFI）による建設プロジェクトで議論される様々なリスク要因の 内で, 地下の地盤・岩盤の幾何学的および力学的条件の不確実性に起因するリスク（以下地下リスクと称 する）に着目し, その評価方法および分担方法について検討を加えるものである. 具体的には, 従来の建 設請負契約での地下リスクの分担法について示すと共に, PFIでは地下リスクを請負者が負担する可能性 があることを示した. また, 建設プロジェクトでの地下リスクを評価するためには, 地盤条件の変動に関 する平均值および，そのまわりの変動幅を定量化する手法が不可欠であることを明らかにし，その手法と してのクリジング手法の適用性について，実際のボーリングデータを用いて検討を加えた.
\end{abstract}

Key Words : PFI, geotechnical risk, risk management, contract administration, geo-statistics

1.はじめに

昨今の経済不況に加えて, 今後の高齢化・少子化に 伴う税収の減少が予想される状況の下で, インフラス トラクチャーの建設および運営に対して, 民間資本活 用方式 (Private Finance Initiative, 以下 PFI 方式と称す る）の導入が注目されている. PFI 方式の特徴は, 従 来の公共団体である発注者主導の実施形態に代わり, プロジェクトの建設だけでなく運営も民営会社に包括 して発注されるものである. このため, PFI 方式を導 入した場合には, プロジェクト推進のための基本的構 造が, 従来は発注者と請負者との二者で成立っていた のに対して, 公共団体から権限を委譲されるプロジエ クト会社（Single Purpose Company, SPC）, EPC (Engineering Procurement Construction) コントラクター, OM (Operation and Maintenance) コントラクター, 金 融機関および，下請負者（建設・据付等）等の様々な 参加者により構成されるものとなる ${ }^{1)}$. また, 従来の 発注方式では, 公共団体が原則的に負ってきたプロジ
エクト全体（完工・操業）のリスクが，原則的にはプ ロジェクト会社, EPC コントラクターおよび OM コ ントラクターにより負担されることになるため, プロ ジェクト自体のリスク評価および対応が重要な検討課 題となる.

現状では, PFI 方式のプロジェクトのリスクマネジ メントに関する研究としては, 主としてプロジェクト の事業評価としての採算性を議論するため, 操業後の ファイナンシャル・リスクに対する評価および対応に ついての検討が報告されつつある ${ }^{2)}$. しかし, 採算性 を論じる上での初期条件となる, 完工までに要する建 設費に含まれるリスクについての検討は必ずしも十分 とはいえない. 中でも, 建設工事で対象とする地下の 地盤・岩盤の幾何学的および力学的条件の不確実性に 起因するリスク（以下地下リスクと称する）は, 建設 費用および建設工期に多大な影響を与えるリスク要因 であるにも関わらず，これまでに十分な検討がなされ ているとはいいがたい.

この理由は，従来の日本での建設契約では，地下リ 
表-1 代表的建設契約約款における地下リスクの分担ルール

\begin{tabular}{|l|c|c|c|}
\hline \multirow{2}{*}{ 契約約款 } & \multirow{2}{*}{ 発注形式 } & \multicolumn{2}{|c|}{ 地下リスク分担 } \\
\cline { 3 - 4 } & 発注者 & 請負者 \\
\hline 公共工事標準請負契約約款 & 設計・施工分離 & $\bigcirc$ & \\
\hline FIDIC Red & 設計・施工分離 & $\bigcirc$ & \\
\hline FIDIC Yellow & 設計・施工一括 & $\bigcirc$ & \\
\hline FIDIC Silver & EPC/ターンキー & & $\bigcirc$ \\
\hline
\end{tabular}

スクによる変動は, 原則的にはディープポケットを持 つ公共団体等の発注者により負担されてきたことによ ると推察される. すなわち，地下リスクのような予見 することが困難なリスク要因に起因する設計変更は, 数量精算や新工種単価設定がなされることで, 請負者 のリスクが基本的には回避されてきた. ただし，これ は, 発注者である公共団体の財務体力が大きいため, 精算数量が当初契約数量より増大しても, その増額精 算が可能な環境にあったことに留意する必要がある.

これに対して, PFI 方式での発注者となるプロジエ クト会社が, 定量化することが困難な予期しない地盤 条件に起因する地下リスクを負担することは，スポン サーおよび金融機関からの出融資が単独プロジェクト のみに限定されるプロジェクト・ファイナンスの枠組 みでは, プロジェクトの実行可能性にかかわる.この ため, 建設段階で発生する地下リスクは，その建設契 約の構造から，プロジェクト会社から EPC コントラ クターへ, そして EPC コントラクターから建設・据 付等の下請負者へと分配・転嫁されることになる.

しかし，これまでの建設プロジェクトを対象とした リスク分析に関する事例研究 ${ }^{3)}$ にも示されているよ うに, リスク分担能力の低いプロジェクト参加者への 不適切なりスク分配・転嫁は，新たなりスク連鎖を引 き起こし，プロジェクトを遂行する上で重大な支障と なる危険性を含んでいる. PFI 方式のプロジェクトで は, プロジェクト会社および EPC コントラクターは, 従来の公共団体に比べてリスク分担能力の低いプロジ エクト参加者であるため, 両者の間での地下リスクの 分配ルールは, 極めて慎重に立案する必要がある.

また, 筆者ら ${ }^{4)}$ が示したように, 昨今欧米の建設マ ネジメント分野では, 従来の契約管理に基づくリスク 対応への反省から Partnering () という対処方法の有効性 が指摘され始めている. この基本概念は, 発注者と請、 負者の両者が分担しなければならないリスク要因につ いては, 発注者と請負者の両者が協力し, そのリスク 要因による変動が発生する危険性を出来るだけ少なく するものである.
この Partnering の概念を地下リスクに適用すれば, 地質調査の精度を高めることはもちろんのこ之, 設 計・施工両面から発注者・請負者共に地下リスクの評 価・低減に対する新しい試みが必要不可欠な事項とな る. また同時に, プロジェクト会社, EPC コントラク ターおよび下請負者の 3 者が, 工事前・工事中を通じ て，地下リスクの評価および対応について，共通の認 識を形成することが不可欠な事項となる.

このような観点から, 本研究では PFI 方式による建 設プロジェクトにおける地下リスクの取り扱いについ て検討を加えるため, 以下の事項について示す.

(1) 代表的な建設契約約款における地下リスクの分 担ルール

(2) PFI 方式による建設プロジェクトにおける地下 リスクの取り扱い

(3) 地下リスクの評価方法としての地盤統計学の適 用性

最後に, これらの事項を踏まえて, 今後建設プロジ エクトに内蔵される地下リスクに対して, 合理的に対 応する方策についても考察を加える.

\section{2. 代表的建設契約約款における地下リスク分 担ルール}

本章では, 建設プロジェクトを推進する上で重要な 課題となる地下リスクについて, 代表的な建設契約約 款でのリスク分担の基本概念について述べる.

\section{（1）代表的な建設契約における地下リスクの分担ル ール}

ここでは, 代表的な建設請負契約の事例として, 国 内建設工事に適用されている公共工事標準請負契約約 款のおよび，海外工事において通常適用されている FIDIC ${ }^{7), 8), 9)}$ を取り上げる. これらの契約約款におけ る地下リスク分担ルールの要約を表-1 に示すと共に, その内容について以下に示す. 


\section{1) 公共工事標準請負契約約款}

従来の日本における公共工事の発注形態では, 公共 団体の実施機関が発注者となり, 設計・施工分離の原 則の下で, コンサルタントが発注者に対して入札，契 約および施工監理等を補佐し，施工は請負者により害 施される.この公共工事での発注者と請負者の間で採 用される建設請負契約が, 公共工事標準請負契約約款 である.この請負契約は, 原則的には総価一括契約で ある.この契約では, 地下リスクのような予見するこ とが困難なリスク要因に対する設計変更は, 草柳 ${ }^{10)}$ が指摘しているように, 当契約約款に記載されている, 「信義則」に基づき甲乙が友好的に問題の解決を図る という精神に則り対処される. 実際には, 発注者の判 断により, 数量精算や新工種単価設定がなされること で, 請負者のリスクは基本的には回避される.ただし， 設計変更を実施する決定は発注者の判断に基づくもの であるため, 請負者のリスクがすべて回避されてきた ものではないことに留意する必要がある. また, 不完 全ながらも地下リスクは発注者により負担されるとい うリスク対応の基本条件は, 精算数量が当初契約数量 から増大しても, 発注者の財務体力がその増額変更に 十分対応可能であることに留意する必要がある.

\section{2) FIDIC}

海外工事において通常適用される建設請負契約は FIDIC と総称され, その約款は発注形式により, 以下 のように分類される.

- FIDIC Red ${ }^{7} \quad$ （設計・施工分離方式）

$\cdot$ FIDIC Yellow ${ }^{8)}$ (設計・施工一括方式)

- FIDIC Silver $\left.{ }^{9}\right) \quad$ (EPC/ターンキー方式)

この内, FIDIC Red は, 設計・施工分離の建設工事 に適用される数量精算契約（Re-measurement 契約）に 基づく請負契約約款である.この契約では, 入札段階 で発注者側から工事単価数量表（Bill of Quantities; 以 下 BOQ と称する）が提示され, 請負者がその数量表 に示される各項目の単価を設定し，それを集計するこ こで入札価格を定め応札するものである. このため, 予期しない地盤条件の出現により，例えば掘削土量あ るいは支保部材の数量が当初見積りから増加したとし ても, その数量に対する工事費の增加は, 発注者によ り負担される. すなわち, 地下リスクは基本的には発 注者が負担することとなる. ただし，この方法では数 量増減は精算されるが, 単価は変更されないこともあ り, 請負者が地下リスクを負う可能性があることに留 意する必要がある.

次に, FIDIC Yellow は設計・施工一括方式の工事に 適用される請負契約約款である. ただし，この契約の
基本概念は, 数量精算契約（Re-measurement 契約）に 基づく請負契約約款であり，その記述は FIDIC Red と 同じ記述が用いられている。したがって，FIDIC Yellow での地下リスクの分担ルールは, FIDIC Red と 同様である.

これに対して, FIDIC Silver は, いわゆる EPC/タ ーンキープロジェクトに対する契約約款である. その 特徴は, 発注者すなわちプロジェクトオーナーは, 完 成物の要求性能を明示すると共に, 地下条件を含めて 保有するすべての情報を入札者に提示するが，応札者 は必要があれば自己の負担で追加調査を行い, その結 果に基づき設計・施工計画を立案し入札することであ る. この前提条件では, 請負者すなわち EPC コント ラクターが, 地下リスクを負うことになる. もちろん, FIDIC Silver のガイドラインは，この約款を適用する ことが不適当である場合に関する記述もあり, 条件が 整わない場合でもすべてのリスクを請負者に分担させ ることを戒めているが, 事業規模が公共団体に比べて 小さいプロジェクト会社にとっては, リスク転嫁を行 う上で有効な契約約款であるといえる. 現状では, FIDIC Silver が適用された事例はほとんど報告されて いないようであるが, EPC/ターンキープロジェクト に対する契約約款となる, FIDIC Silver における地下 リスクの取扱いについては, 今後重要な検討課題にな る可能性があるものと推察される.

\section{（2）地下リスク分担に関する考察}

一般に, 地盤・岩盤を対象とした建設工事では, 地 下リスクは予見することが困難なリスク要因として認 識されているが，このリスク要因への対応は, 以下の ように大別される.

・調査工事（ボーリング調査・地盤試験等）

・施工段階での設計変更 (数量精算)

なお, 従来調査工事は発注者の負担により実施され るため, 調査工事は地下リスクの回避策と認識されな いことが多いが, ここではプロジェクトの地盤条件に 関する不確定要素を減じるという解釈の下で, 調査工 事をリスク対応の一方策として取り上げる.

(1)で述べたように, 公共工事標準請負契約約款, FIDIC Red および FIDIC Yellowに基づく建設プロジェ クトでは, 発注者の実施した調査工事に基づく情報が 応札者に提供されることが前提条件であるため, 請負 者は調査によるリスク対応とは無関係である.

これに対して, FIDIC Silver に基づくプロジェクト では, 地下条件は発注者により入札者に提示されるが, 請負者（EPC/コントラクター）は必要があれば自己 の負担で追加調査を行い, その結果に基づき設計・施 工計画を立案するため, 請負者も調査によるリスク対 


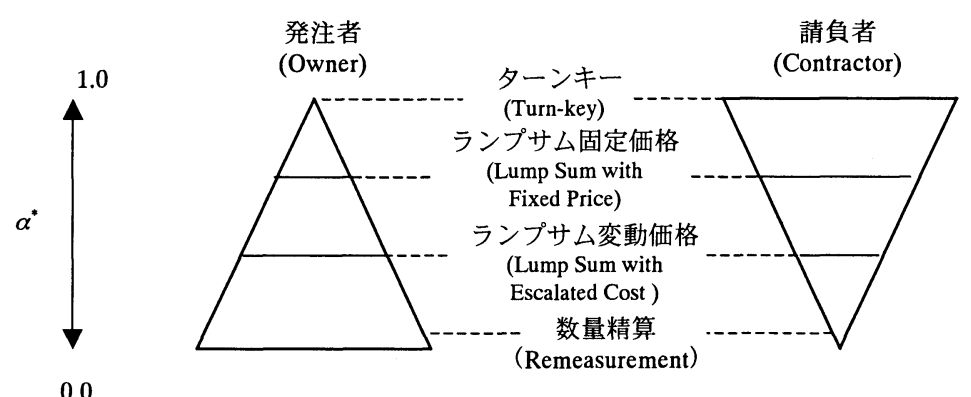
a) 発注者の平均的分担率: 1- $\alpha^{*}$
b) 請負者の平均的分担率: $a^{*}$

図-1 契約による発注者と請負者のリスク分担率の変動（模式図）

応を図ることが必要となる可能性がある.

次に，施工段階での地下リスクは，(1)で述べたよ うに, FIDIC Silver のような EPC／ターンキー契約を 除いて，原則的には通常の建設請負では，建設工事中 に実施される数量精算により，発注者が負担すると解 釈される.しかし，前述のように，既存の方法では数 量増減は精算されるが，単価は変更されないこともあ り，請負者が地下リスクを負う可能性があることに留 意すべきである.

ここで，地下リスクに起因する変動額 $\Delta P$ を発注者 と請負者の両者が分担するという仮定条件の下で，そ れぞれの変動額の負担額すなわちリスク分担は，以下 のように表される ${ }^{5}$.

1) 発注者の負担額

$$
\Delta P_{o} \cong\left(1-\alpha^{*}\right) \Delta P
$$

2) 請負者の分担額

$$
\Delta P_{c} \cong \alpha^{*} \Delta P
$$

ここに， $\alpha^{*}$ は全地下リスク要因に対する平均的なリス ク分配率を表し，0から10間の值となる.

式(1)〜式(2)に示す関係で, EPC／ターンキー契約 (EPC 契約と称す) および数量精算契約（RM 契約と 称す）での，最も簡単な場合のリスク分配は次のよう に表される. すなわち，請負者のリスク分担が大きい EPC 契約では分配率 $\alpha$ は 1.0 に近くなり，一方請負者 のリスク分担が小さくなる $\mathrm{RM}$ 契約では分配率 $\alpha^{*}$ が 0.0 に近くなる. もちろん, 変動額 $\triangle P$ は多様なリスク 要因によるコスト変動の集合であるため, 上記のよう な単純な関係にはならない. しかし，EPC契約での平 均的なリスク分配率 $\alpha^{*}$ は 1.0 に近い值となるはずであ
り, 一方 RM 契約での平均的なリスク分配率 $\alpha^{*}$ は 0.0

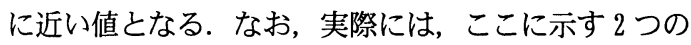
方式を何らかの形に修正した契約方式が採用されるケ 一スが多いが，どのような契約を用いたとしても， 図-1 の模式図に示すように，平均的なリスク分配率 $\alpha^{*}$ は 0 と 1 の間となるため, ここに示す議論の基本思 想は変化しない.

したがって，地下リスクはいずれの契約方式を用い た場合にも，発注者と請負者によって負担されるもの であり，そして PFI 方式を導入することにより請負者 のリスク分配率 $\alpha^{*}$ 大゙大くなるだけである. このため, 地下リスクに起因する変動額 $\Delta P$ 自体を低減すること が根本的な解決方法となる.このためには，地盤調査 の精度を高めることはもちろんのこと, 設計・施工両 面からは発注者・請負者共に地下リスク評価の新しい 試みが必要不可欠な事項となる.

\section{PFI 方式の建設プロジェクトにおける地下リ スクの取り扱い}

本章では, PFI 方式による土木工事を主体とする建 設プロジェクトの執行形態について示すともに, 地下 リスクに対応する上での課題について検討を加える ${ }^{4)}$.

\section{（1）PFI による建設プロジェクトの実施形態}

PFI による建設プロジェクトの実施形態は, 従来の 公共事業の場合と異なり, プロジェクト会社, EPC コントラクター，金融機関および，下請負者（建設・ 据付等）等の様々な参加者により構成される. 現在日 本で計画・実施中の PFI 方式の建設プロジェクトは, 建設段階での不確定要因が比較的少ない建築構造物が 主体であるが，世界的には PFI 方式が土木工事主体の 建設プロジェクトへ適用された事例も数多く挙げられ 
表-2＼cjkstart海外における水力PFI（BOT）事業の事例

\begin{tabular}{|l|c|c|l|c|l|}
\hline プロジェクト名 & 国 & $(\mathrm{MW})$ & \multicolumn{1}{c|}{ レイアウト } & 契 約 & \multicolumn{1}{c|}{ 備 考 } \\
\hline Casecnan & フィリピン & 150 & 地下発電所 & EPC & Construction(00) \\
\hline San Roque & フィリピン & 345 & ダム(200m)・トンネル & EPC & Finance closed (99) \\
\hline Bakun & フィリピン & 70 & 地上施設 & EPC & Operation (01) \\
\hline Theun Hinboun & ラオス & 210 & 地上施設・トンネル & Non EPC & Operation (98) \\
\hline Houay Ho & ラオス & 150 & ダム(77m)・トンネル & Non EPC & Operation (00) \\
\hline Khimti I & ネパール & 60 & 地下発電所 & Non EPC & Construction(00) \\
\hline Birecik & トルコ & 672 & ダム (62m) & EPC & Construction(00) \\
\hline Ita & ブラジル & 1,450 & ダム(125m) & EPC & Construction(00) \\
\hline Guilman-Amorin & ブラジル1 & 140 & ダム (41m)・トンネル & EPC & Operation (98) \\
\hline
\end{tabular}

注) レイアウト欄および備考欄の（）内数字は，それぞれダム堤体高および西暦を表す.

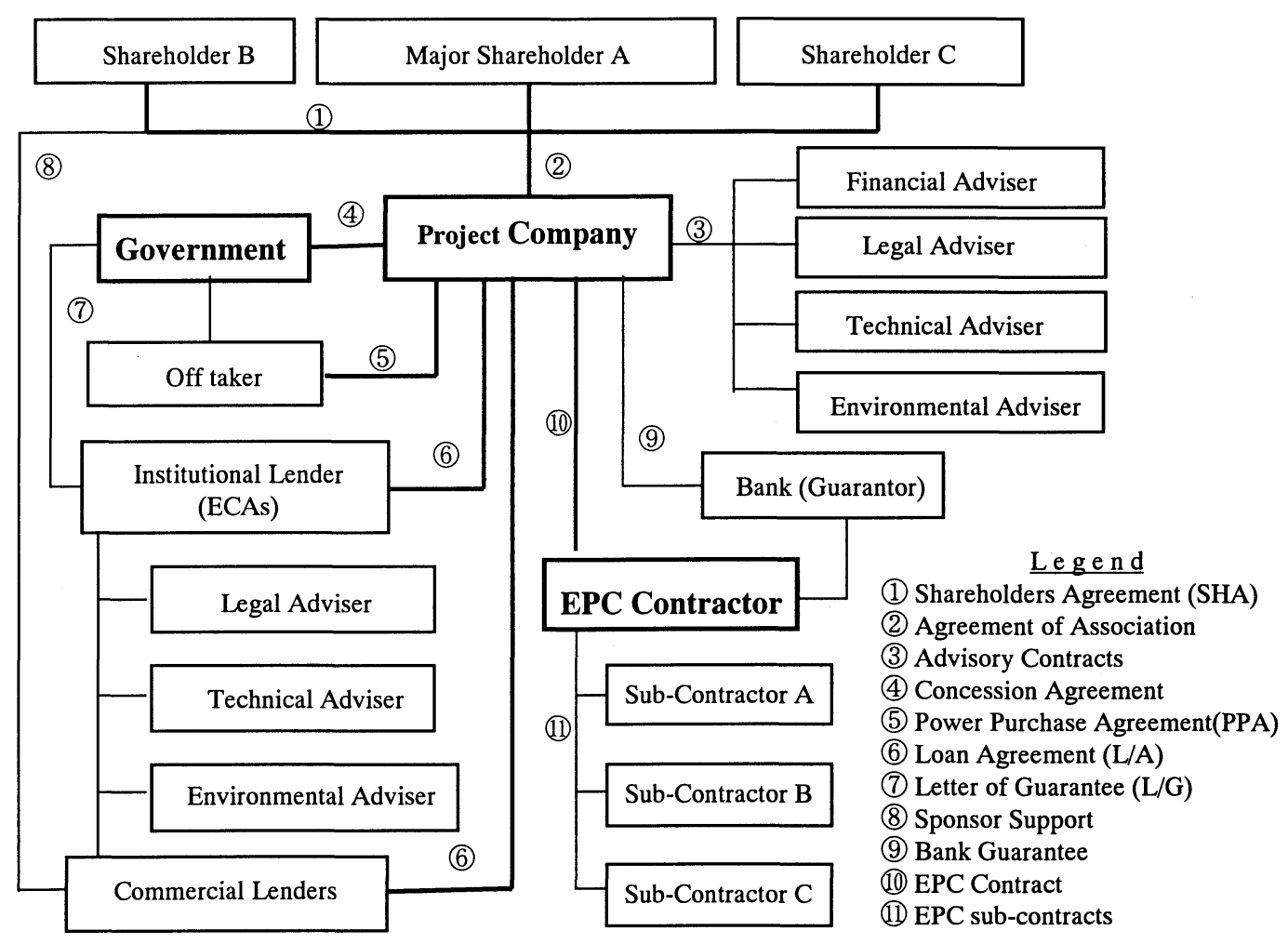

图-2 PFI 方式による建設プロジェクトの契約形態例

る. 例えば，表-2 に示すように，ダム基礎の遮水性 あるいは, 地下発電所での周辺岩盤の安定性等の, 地 下リスクを含む土木工事である, 水力発電所建設プロ ジェクトが PFI（BOT）事業として現在進行中である. なお, 同表に示した事例は, 筆者らの調査および世界
銀行の資料 ${ }^{11)}$ から作成したものであり，その他にも 電源開発事業のコンセッションが付与された案件も多 く報告されているが, ここではファイナンス・クロー ズしたとされる案件例のみを示した. また, 既設買収 により民間プロジェクトとなった案件も除外している. 
同表に示す事例では, ラオスおよびネパールでのプロ ジェクトを除いて, その他のプロジェクトでは EPC 契約が採用されており, EPCコントラクターが，地下 リスクを含む多様なリスクを負担するプロジェクト形 態となっている.

次に, 表-2に示す PFI（BOT）方式のプロジェクト事 例を対象として, その実施形態について筆者らが調査 した結果を図-2 に示す. 同図に示す実施形態での主要 な契約としては, 以下の契約が挙げられる.

1) 政府機関とプロジェクト会社の間で締結されるコ ンセッション契約（図-2 の(4)）

2) プロジェクト会社と金融機関（レンダー）の間で 締結される Loan Agreement（図-2 の6)）

3) プロジェクト会社と EPC コントラクターの間で締 結される EPC契約（図-2 の99)

4) EPC コントラクターと下請け会社との間で締結さ れる建設・据付等に関する契約（図-2 の(11)

この内，地下リスク関連する契約は，プロジェクト 会社と EPC コントラクターの間で締結される EPC契約 と, EPC コントラクターと下請け会社との間で締結さ れる建設契約である. プロジェクト会社と金融機関の 間で締結される Loan Agreement 契約（以下 L/A と称す る）は, プロジェクトの地下リスクとは直接には関連 しないが，そのリスク分担の基本概念には大きな影響 を与える.

PFI 方式でのプロジェクトでは，これまでのコーポ レート・ファイナンスに代わり, プロジェクト・ファ イナンスが検討される. プロジェクト・ファイナンス では，投資家に加え金融関係者も貸し手責任を負うこ とになるため，事業投資家および金融関係者は，プロ ジェクト会社が, プロジェクトが内包するリスクを厳 しく評価し, キャッシュフロー・モデルに基づき配当 収益率やデットサービスカバーレシオ(DSCR)等の事 業収益性に関わる指標を正確に算出することを要求す ることになる. 仮に, プロジェクトが内包するリスク が大きく, その事業収益性に不確定性が多い場合には, プロジェクト・ファイナンスによる融資が決定されな いケースも想定される.

このような課題に対して, 詳細設計および建設工事 をあわせて分担することで合理的にプロジェクトのリ スク管理する方策として, プロジェクト会社と EPC コ ントラクターの間に EPC/ターンキー契約が締結され ることになる. なお,この EPC/ターンキー契約の 下では, プロジェクト会社のリスクが EPC コントラク ターへと転嫁されることになるため, .EPC コントラク ターがプロジェクトの最大のリスク分担者になるケー スがあることに留意する必要がある.

しかし，地下リスクのように予見することが困難な
リスクに対しても，EPC/ターンキー契約において, 上記のような解釈が可能か否かは重大な課題を含んで いる. 2．に示したように, FIDIC Silver の適用事例 がほとんどないことおよび，そのガイドラインで, 条 件が整わない場合でもすべてのリスクを請負者に分担 させることを戒めていることからも，現状では EPC ノターンキー契約での地下リスク分担ルールは確定し ていないことに留意する必要がある. すなわち, 安直 なリスク分配ルールの適用は, その分配されたリスク がプロジェクト会社〜EPC コントラクター〜建設・据 付等の下請負者へと転嫁されることで新たなリスク連 鎖を誘発し, プロジェクトを遂行する上で重大な支障 となる危険性を含んでいる. したがって，地下リスク については, EPCコントラクターだけではなく, プロ ジェクト会社, あるいは何らかの公益性が認められる 場合には一部を公共団体も分担する方策について検討 する必要があると推察される.

このような観点から，地下リスクが支配的となる土 木工事において PFI 方式を導入するためには，プロジ エクト会社および EPC コントラクターは, 完工まで リスク評価の精度および，その対応策について検討す ることすなわち, リスク管理能力を高めることが不可 欠な課題となる. 中でも, プロジェクト・ファイナン スの基本思想から，出資者・金融関係者の合意を得る ため, プロジェクト会社および EPC コントラクター の協力による, 地下リスクの定量化に関する検討も緊 急の課題となる.

\section{（2）地下リスク対応の課題}

2.において述べたように，地下リスクに対する対 応の基本は, ボーリング調查および試験等による地 盤・岩盤調査である. いうまでもなく, 地盤・岩盤調 查費用は, 従来の公共工事では実施母体の公共団体に より負担されてきた. PFI 方式のプロジェクトでは, 様々な実施形態となることが予測されるが, この調査 費用は原則的にはプロジェクト会社により負担される.

ただし, 一般に地下の地盤条件は, 空間的分布特性 等に代表される多くの不確実な要素を含んでいる.こ れに対して, 実際にボーリング調査結果より得られる デー夕は点情報の集積である.このため，その点情報 の単純な内挿あるいは外挿により推定される地盤条件 の信頼性には課題があることは, これまでにも認識は されてきた. しかし, 従来の公共団体主導の建設プロ ジェクトでは，この地質調査に関する信頼性を高める ことよりは，その地下リスクに起因する施工条件の変 化は設計変更により対処することが主であった. すな わち, 従来の日本での建設契約では, 地下リスクによ る変動は, 原則的にはディープポケットを持つ公共団 
体等の発注者が数量精算や新工種単価設定を行うこと で負担され，請負者のリスクが基本的には回避されて きた.これは，1．で述べたように，発注者である公 共団体の財務体力が大きいため, 精算数量が当初契約 数量より増大しても, その増額精算が可能な環境にあ ったことによる.これに対して，スポンサーおよび金 融機関からの出融資が単独プロジェクトのみに限定さ れるプロジェクト・ファイナンスの枠組みでは, 定量 化することが困難な予期しない地盤条件に起因する地 下リスクを負担することは，プロジェクトの実行可能 性にかかわる. したがって，ボーリング調查等の結果 より得られる地盤条件の信頼性に関する検討が，これ まで以上に重要になるものと推定される.

ここで，調査より得られる地盤条件の信頼性につい て考察する. 先にも述べたように, 地盤条件は本来地 盤の幾何学特性（地層分布・層厚等）および，力学的 特性（変形性・強度特性等）については変動幅を有す るはずである.この変動幅を有することを認めた場合 には，設計結果に基づく建設コストも幅を有する値と なる. 例えば，模式的に図-3 の 1)に示すように, 発 注者により実施された初期の調查結果から推定される 建設コストは, 本来平均值 $\mu_{\mathrm{F}}$ と標準偏差 $\sigma_{\mathrm{F}}$ を有する ものになると推察される，なお，図-3では議論を明 確にするために，建設コストを正規分布モデルとして 例示した. もちろん, 実際のコスト分布はより複雑な ものになると推定されるが, 調査段階の地下リスクを 定量化する方策に関する，ここでの議論の基本思想は 変化しない.

つまり, 従来の建設プロジェクトでの設計およびコ ス卜推定は, 平均值 $\mu_{\mathrm{F}}$ のみを用いて検討がなされ， その変動幅（標準偏差 $\sigma_{\mathrm{F}}$ 之等価）について議論され ることは極めて稀であった. しかし，PFI 方式では， 発注者となるプロジェクト会社は, 地下リスクに起因 するコストの変動幅を議論することが不可欠となる. 例えば, 平均値 $\mu_{\mathrm{F}}$ まわりの変動幅（金融工学で定義 されるアップサイドリスクと等価）を建設コストの予 備費として設定することが，必ずしも十分に技術的な 知識を有していない, 出資者および金融関係者に地下 リスクに関する合意を得る上で最も有効な情報になる と推定される.

次に, 地盤調查の信頼性と, 調査費との関係につい て考察する. いうまでもなく, 調査費用を掛けること で, 地盤調查の信頼性を高めることは可能となるが, 民間であるプロジェクト会社では, どの程度の費用を 調査に割り当てるかが極めて重要になる. また, 2. の EPC/ターンキー契約の契約約款となる FIDIC Silver のガイドラインにおいて示したように, 発注者 から提示される情報が不十分とした場合には，その追

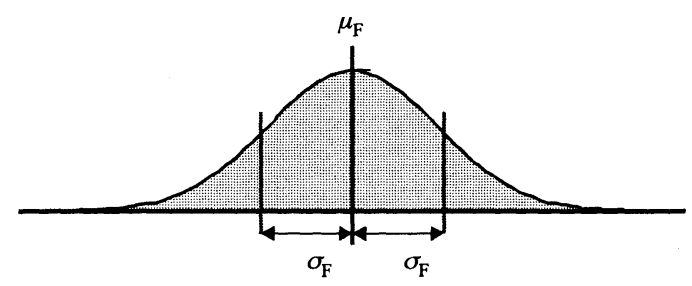

1）初期調査段階で想定されるコスト変動

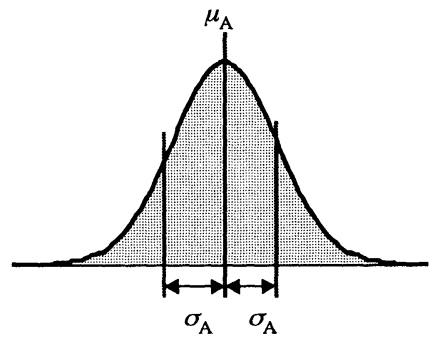

2）追加調查後に想定されるコスト変動

図-3 調査結果から推定されるコスト変動（模式図）

加調査費用は EPC コントラクターの負担になる可能 性もあるため, 請負者にとっても調査費用とその信頼 性の関係は極めて重要な検討課題となる.

ここで，追加調査を実施することにより，想定され る建設コストのアップサイドリスクが減少すると仮定 する. 議論を明確にするため, 追加調查後に想定され るコスト変動が, 模式的に図-3 の 2)に示すように, 平均值 $\mu_{\mathrm{A}}$ および標準偏差 $\sigma_{\mathrm{A}}$ でモデル化されると仮定 すれば， $\sigma_{\mathrm{F}}$ と $\sigma_{\mathrm{A}}$ について以下の関係が成り立つもの と推察される.

$$
\begin{gathered}
\sigma_{F} \geq \sigma_{A} \\
B=\sigma_{F}-\sigma_{A}
\end{gathered}
$$

ここに， $B$ は追加調查を実施することによる建設コス トの変動幅の低減量すなわち便益を表す。したがって, 追加調查の投資対効果を考える場合には，理論的には 便益 $B$ と追加調査に必要な費用との大小関係から, 詳細設計の有効性が示されることになる.

したがって, PFI 方式による建設プロジェクトでの 地下リスクを評価するためには，図-3 および式(3)に 示すような表現が可能となる, 地盤条件の変動に関す る平均値および，そのまわりの変動幅を定量化する手 法を適用することが不可欠な事項となる. 


\section{4．地盤構造リスク評価への地盤統計学の応用}

本章では, ボーリング調査結果より推定される地盤 条件の信頼性を定量化する手法として, 地盤統計学の 代表的な手法であるクリジング手法の基本概念 ${ }^{12), 13)}$ を示すと共に, 実際の地盤での適用結果に基づき, そ の手法の適用性について考察を加える.

\section{（1） クリジング手法の基本概念}

クリジング手法は, 不偏線形最適推定法 BLUE (Best Linear Unbiased Estimator) と呼ばれる方法の一 種であり, 推定すべき值 $Z_{0}^{*}$ （不偏推定值）が, 次式 に示すような計測結果に基づく線形式により表される と仮定する.

$$
Z_{o}^{*}=\sum_{i} \lambda_{0}{ }^{i} Z_{i}
$$

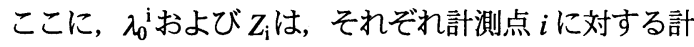
測値, 重みを表す.

また, 対象とする計測值に対して 2 次のモーメント までの定常性を仮定すると, 位置 $x$ に存在する值 $z(x)$, その位置から $h$ だけ離れた位置の值を $z(x+h)$ とする 時, この 2 点間での計測值の空間的分布特性を表す, セミバリオグラム $\gamma(h)$ は以下のように定義される.

$$
\left.\gamma(h)=\frac{1}{2} E\{Z(x+h)-Z(x)\}^{2}\right\}
$$

ここで, $E\{\cdot\}$ は期待值を表す記号である.

なお, 式(5)に示すセミバリオグラム $\gamma(h)$ の関数形 としては, 指数関数, 球関数及び線形関数等の様々な 関数形が提案されており，その計測結果に対する関数 近似の最適化手法としては, 最尤法, 赤池情報基準 AIC を用いた方法あるいは，非線形最小自乗法等が適 用される.

次に, 式(4)および式(5)の関係式において, 未知数 となる重みを合理的に算定する上で, 不偏性と推定誤 差最小化の仮定を導入する. ここで, 誤差を最小化す るためにラグランジュの未定係数 $\mu$ を導入する.

最終的には，以下に示す連立方程式を解くことによ って, 変数 $\lambda_{0}{ }^{\mathrm{i}}$ および $\mu$ が得られる.

$$
\begin{gathered}
\sum_{j} \lambda_{0}{ }^{j} \gamma\left(x_{i}-x_{j}\right)+\mu=\lambda_{0}{ }^{i} \gamma\left(x_{i}-x_{0}\right) \\
\sum_{i} \lambda_{0}{ }^{i}=1
\end{gathered}
$$

ここで得られる変数 $\lambda_{0}^{\mathrm{i}}$ を式(4)に代入することで, 最尤推定值が算定される.

さらに, 誤差推定分散 $\sigma_{\mathrm{E}}^{2}$ は, 以下のように算定さ れる.

$$
\sigma_{E}^{2}=\mu+\sum_{i} \lambda_{0}^{i} \gamma\left(x_{i}-x_{0}\right)
$$

ここで, $x_{0}$ は最尤推定值を算定する箇所の位置座標を 表わす.

以上の定式化において，図-3に示す地下リスク評 価の基本条件となる, 地盤条件の変動に関する平均値 および，そのまわりの変動幅を定量化することが可能 となる．具体的には，式(4)に基づき算定される最尤 推定値が平均値に相当し, また式(8)に基づき算定さ れる誤差推定分散が分散に相当する.

\section{（2） クリジングの地下リスク評価方法としての適用 性に関する考察}

クリジング手法の地下リスク評価手法としての適用 性について検討する事例として, 図-4 に示す大阪湾 河口付近の河川堤防基礎地盤を取り上げる. 同図に示 すように, 基礎地盤は, 洪積層および沖積層（砂首・ 粘土層）から構成されている.

当地点での洪積層は，一般に杭基礎および，山留め 壁に支持層となっている，沖積砂層は，液状化に可能 性があるゆるい砂であり，沖積粘土層は，大きな沈 下・側方流動を生じる危険性のある軟弱粘土である.

したがって, 当地点に建設される地盤構造物の基本設 計段階では, 各層の強度特性に加えて, 支持層の深度 および各層の層厚等の幾何学的特性が重要な検討項目 となる.

このような観点から，本検討では，図-4 に示す河 川堤防基礎地盤に対して, 設計上で幾何学的パラメー 夕となる, 支持層となる洪積層の深度および沖積層 (砂層・粘土層) の層厚についての空間的分布特性に 着目する.

なお，この事例では，実際には河川堤防右岸・左岸 で堤体に沿って, 平均間隔約 $200 \mathrm{~m}$ でボーリング調査 が実施されている．このボーリング調査結果を用いて, 200m よりボーリング間隔が大きい場合にクリジング 手法を用いて推定される幾何学的パラメータの信頼性 および，ボーリング間隔を小さくすることによる信頼 性の向上について定量的な検討を加えるものとする. また，本検討では式(5)に示すこのセミバリオグラム の関数形としては, 次式に示す指数関数と仮定する. 


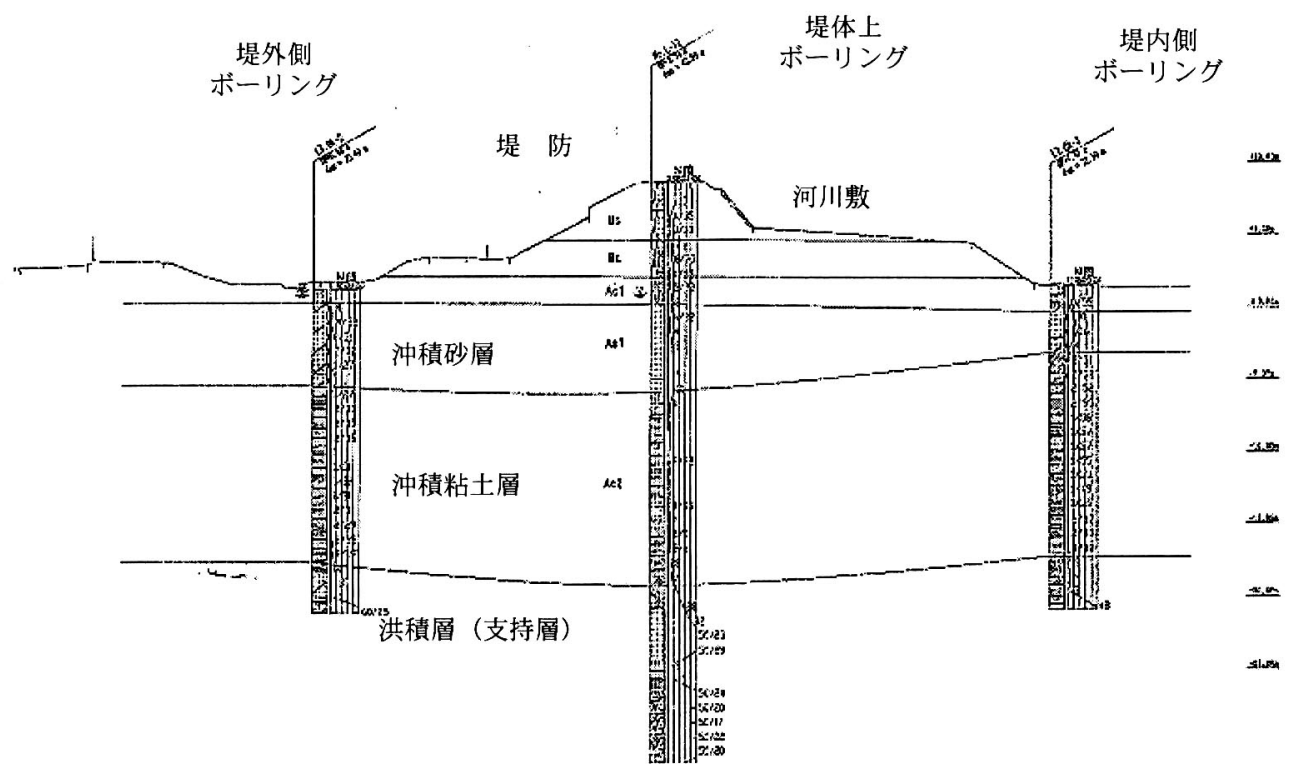

図-4 河川堤防の調査結果

$$
\gamma(h)=C\left\{1-\exp \left(-\frac{\sqrt{(\Delta x)^{2}+(\Delta y)^{2}+(\Delta z)^{2}}}{a}\right)\right\}
$$

ここに, $C$ はシル（理論的には対象とするデータの分 散と等価）および， $a$ はレンジ（影響距離）を表す. また, $\Delta x, \Delta y, \Delta z$ はそれぞれ計測点間の三次元空間 での距離を表す。なお，式(9)に含まれる係数は，対 象とする洪積層表面の深度および各沖積層の層厚毎に, 非線形最小自乗法を用いて算定した。

クリジングによる算定結果の代表例として, クリジ ングに用いたボーリング間隔の平均值が，それぞれ約 $200 \mathrm{~m}$ およ゙約 $800 \mathrm{~m}$ に対応する基盤深度の推定結果 を図-5 に示す，なお，同図に示す結果は，河川堤防 左岸の堤体軸に沿った断面を展開して取り出し，その 断面内での洪積層表面の深度分布の推定結果之計測值 を併せて示したものである，なお，同図に示す実線は クリジング結果での基盤深度の最尤推定值を示し, 破 線はその最尤推定值土推定誤差分散を示す. また, 図 中の横軸は河口からの距離を表す.

図-5 に示す結果で, クリジングに用いたボーリン グ間隔の平均值が約 200mの場合（図-5 (a)）には, 最尤推定値の分布で洪積層表面の微妙な地形の変動が 表現されている. また, 河口から 2,000mまでの多少 ボーリング間隔が長くなっている領域を除いて，推定 䜋差分散は $1 \mathrm{~m}$ 程度であり,ここで推定された洪積層 表面の深度に関する信頼性は十分高いものであると推

\section{察される.}

これに対して，クリジングに用いたボーリング間隔 の平均值が約 $800 \mathrm{~m} の$ 場合（図-5 (b)）には, 最尤推 定值の分布形状は，ボーリング間隔が密な場合と比較 して, 平均的な分布となり微妙な地形の変動が表現さ れていない. また, 実際のボーリング地点を除いて, 推定誤差標準偏差は全体的に 2〜3m程度と, ボーリ ング間隔が密な場合に比べて大きくなっている.

この結果より，地層推定に用いるボーリング間隔が 小さくなること, すなわち調査に対する投資額を大き くすることで, 推定される結果の信頼性は高くなると いう当然の帰結が，定量的に表現されることになる. すなわち，図-5 に示す河川軸に対する計測点を除く 任意の断面を対象とした場合に，その対象断面での推 定䛊差標準偏差の差が，地盤調査に対する投資対効果 を表す指標となる.

ただし，本来調查の精度は，その結果を用いる目的 によって変動する. 建設コストを積算する基本設計段 階で要求される精度と, 詳細設計段階で要求される精 度は当然変化する．例えば，2．（1）で述べたように， FIDIC Silver に示されている内容からすれば, プロジ エクト会社が必要とする調查の精度は, 地質条件から 見た立地可能性であり，建設コストの予備費を算定す る上での数值的根拠となる地盤条件の変動幅である. これに対して，EPCコントラクターが必要とする情報 は, 詳細設計に用いる推定誤差分散が出来るだけ小さ くなる, すなわち地下リスクの少ない調査結果である。 


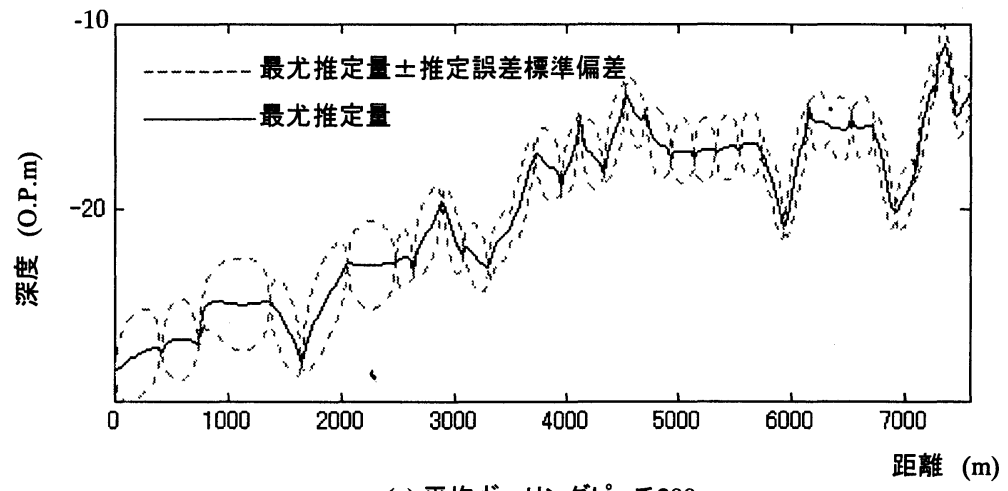

(a) 平均ボーリングピッチ $200 \mathrm{~m}$

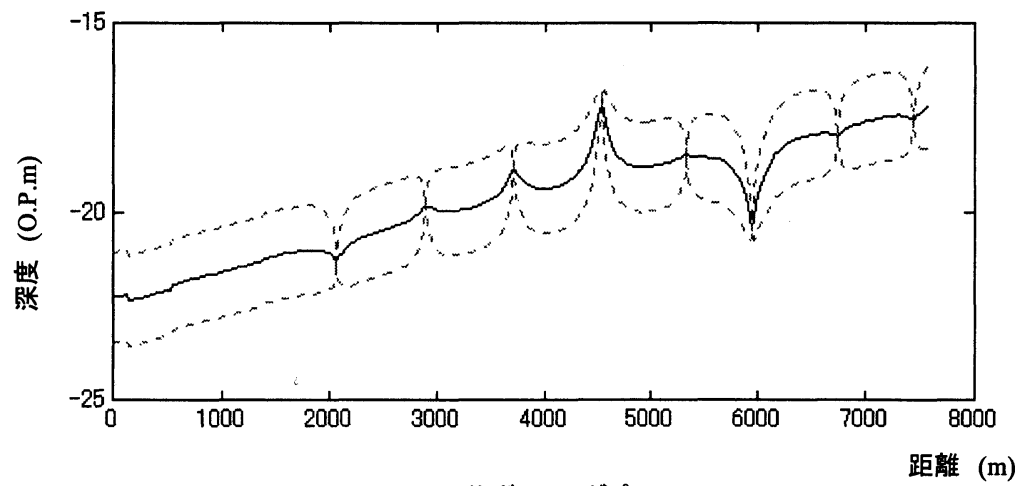

(b) 平均ボーリングピッチ $800 \mathrm{~m}$

図-5 クリジングによる洪積層深度の推定結果

このため, PFI 方式での建設プロジェクトでは, プロ ジェクト会社と EPC コントラクターとの間に発生す る地盤調査の精度に対する要求には, 大きな相違が生 じる可能性がある.

この課題に対処する一つの方策は, いうまでもなく 調查費を増加させること, すなわち, ここでの事例で はボーリング本数を増やすことである. しかし，この 場合には, プロジェクト会社と EPC コントラクター とともに民間会社であり調査費用には限界があること および，その費用を契約上はいずれが負担するかとい う問題が発生する.

上記の課題に対処する方策として，ここではボーリ ング間隔の粗いクリジング結果に基づき地下リスクを 評価する手法の適用性について検討する，具体的には， ボーリング間隔の粗いデータ（平均間隔約 $800 \mathrm{~m}$ ) に 基づくクリジング結果を確率量として取り扱うことで, ボーリング間隔の密なデータ（平均間隔約 $200 \mathrm{~m}$ ）が どの程度の信頼性で推定可能かについて検討を加える.
この検討結果として, 図-6 に図-5 で示した洪積首 表面の深度に加えて沖積層の層厚について, ボーリン グ間隔の粗いデータ（平均間隔約 $800 \mathrm{~m}$ ）に基づくク リジング結果と, ボーリング間隔の密なデータ（平均 間隔約 $200 \mathrm{~m}$ ）との比較を示した. 同図は, 図-5 と同 様に河川堤防左岸の堤体軸に沿った断面を展開して取 り出し, その断面内にクリジング結果と計測結果を併 せてプロットしたものである. また, 図中の実線, 破 線および太線は, それぞれ最尤推定值, 最尤推定值士 推定誤差標準偏差および計測結果を表す.

図-6 に示す各幾何学的パラメータに対する比較結 果より, 以下の事項が明らかとなる.

1) 平均ボーリング間隔 $800 \mathrm{~m}$ のデータに基づく最尤推 定値は, いずれのパラメータについても, 平均ボー リング間隔 $200 \mathrm{~m}$ の計測結果に比べて変化が緩やか な分布となっている.

2) 1)に対して, 平均ボーリング間隔 $200 \mathrm{~m}$ の計測結果 は, ほぼ平均ボーリング間隔 $800 \mathrm{~m}$ のデータに基づ 


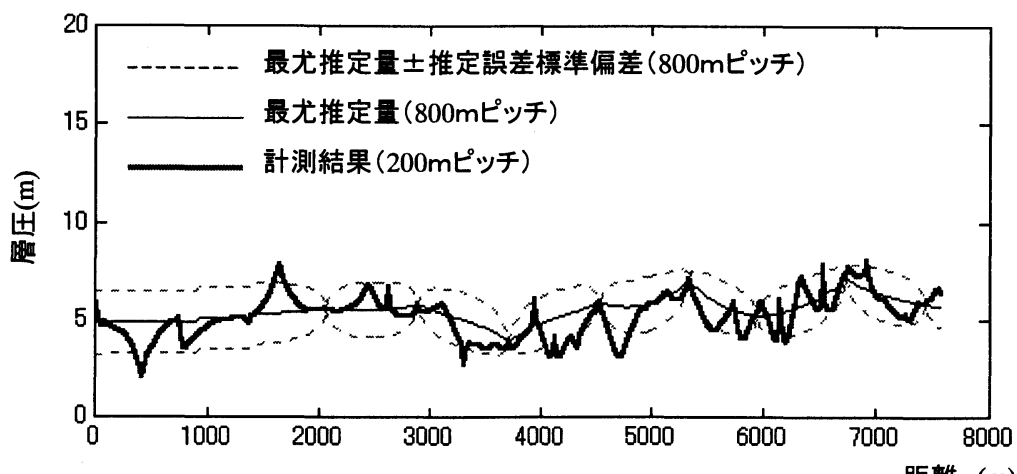

(a) 砂層厚

距離 $(\mathrm{m})$

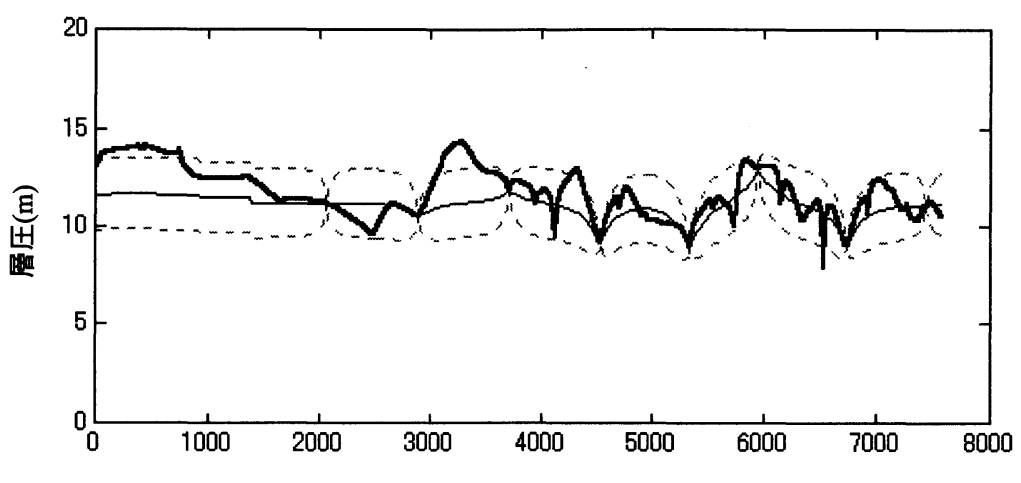

(b) 粘土層厚

距離 $(\mathrm{m})$

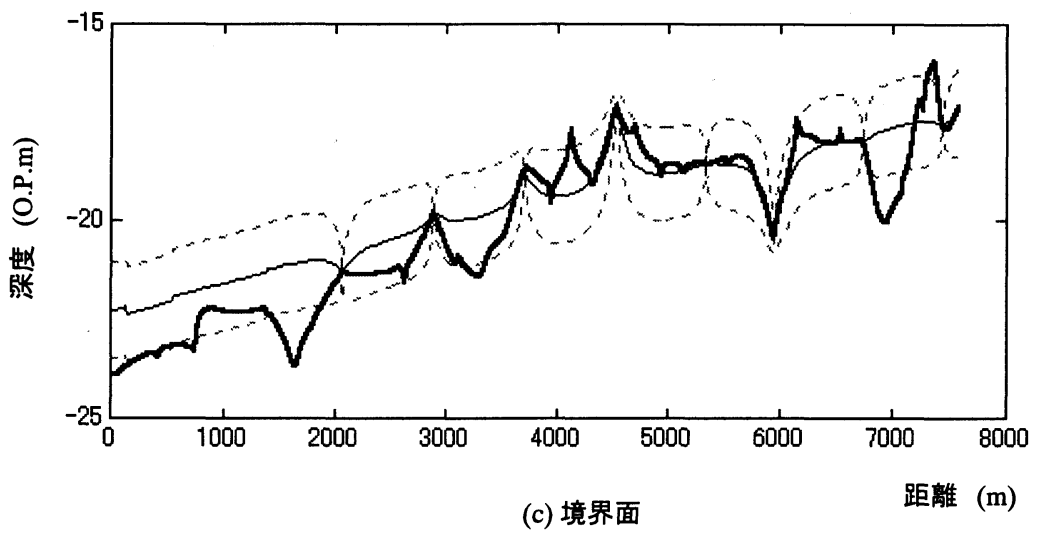

図-6クリジングによる推定結果との計測結果との比較

く最尤推定值士推定誤差標準偏差の範囲内で変動し ている.

このように, 計測データの周辺における予測值を平 均値において確定的に取り扱った基本設計には, 多く の推定誤差が含まれているとともに, その誤差に対応 する概念が構築できない，これに対して，平均ボーリ ング間隔が粗い場合の最尤推定值土推定誤差標準偏差 の変動幅を有する值は, 本検討で提案している, 地盤
条件の変動幅を考慮した基本設計での基礎デー夕とし ての適用性が高いと推察される. その地盤条件の変動 幅を具体的に設計に反映させる方法としては，以下の ようなリスク評価手法が挙げられる.

・クリジングにより算定される任意点での最尤推定值 と誤差推定分散を，それぞれ設計パラメータでの平 均值および分散（標準偏差）とした信頼性モデルに より, 建設コストの変動幅を算定する方法 
・最尤推定值を平均値，また最尤推定值士推定誤差標 準偏差をそれぞれ，金融工学で用いられる上方 VaR（バリューアットリスク） ${ }^{14)}$ および下方 VaR として適用し，建設コスト変動の VaR を算定する 方法

なお，本検討では地盤条件の内，幾何学的パラメー 夕についての結果のみを示したが, 強度定数等の力学 的パラメータについても, 同様な議論が成立つものと 推察される.

次に, 上記の知見に基づく, PFI 方式の建設プロジ エクトでの地下リスク分担の一試案として，以下のよ うな実施手順を提案する.

1) プロジェクト会社は, 地盤調査結果については, クリジング手法等により算定される変動幅を有す る情報として提示するとともに，その変動幅に起 因する建設コストの変動幅を推定する.

2) EPC コントラクターは, プロジェクト会社から 提示される変動幅を有する情報に対して設計・施 工計画を立案し, その建設コストの変動幅を推定 する. この EPC コントラクターによる建設コス ト変動幅は, プロジェクト会社との協議の基礎資 料となる. そして, 両者が合意した後, このリス クはプロジェクト会社により負担されるものとす る.

3） EPC コントラクターは，プロジェクト会社との 協議結果で認められた建設コス卜変動幅を減少さ せることが可能であると判断した場合には, 自己 の負担で追加地盤調查を実施する.

なお，施工段階での地下リスクについては，2．の 代表的契約における地下リスク分担において述べたよ うに，本質的にはプロジェクト会社と EPC コントラ クターの両者により分担されるものである. したがっ て, この課題については, 第三者を含めたプロジェク ト会社と EPC コントラクターの協議機関を設けて, 早期に地下リスクによる両者の損失を低減する方策を 検討・実施することが望まれる．また，このようなプ ロセスは金融機関など他のプロジェクト参加者との調 整も必要となるものと推察される.

\section{5. まとめ}

本研究では, PFI 方式による建設プロジェクトにお ける様々なリスク要因の内で地下リスクに着目し，そ の評価方法および分担方法について検討を加えた. 本 研究により得られた知見は，以下のように要約される。

1) 従来の公共工事では, 地下リスクの大部分が原 則的には発注者により負担されてきたが, PFI 方
式では請負者となる EPC／コントラクターによ る地下リスク負担が増大する可能性がある.

2) PFI に適用されるプロジェクト・ファイナンスの 基本思想から，出資者・金融関係者の合意を得 るため, プロジェクト会社および EPC コントラ クターの協力による, 地下リスクの定量化に関 する検討が緊急の課題となる.

3) PFI 方式による建設プロジェクトでの地下リス クを評価するためには, 地盤条件の変動に関す る平均值および, そのまわりの変動幅を定量化 する手法を適用することが不可欠な事項となる.

4) 2)および 3)の事項より, 調査結果より推定され る地盤条件の信頼性を定量化する手法として, 地盤統計学の代表的な手法であるクリジング手 法を取り上げ，実際の地盤での適用結果に基づ き, その手法の適用性について考察を加えた. その結果として, ボーリングデータを用いたク リジングにより算定される, 最尤推定値士推定 誤差標準偏差の変動幅を有する值は, 本検討で 提案している, 地盤条件の変動幅を考慮した基 本設計での基礎データとしての適用性が高いこ とが明らかとなった。

5) 4)の結果より, クリジング手法の適用を前提と したプロジェクト会社および EPC コントラクタ 一の地下リスク分担方法についても提言した.

本研究においては, 地下リスク要因として地盤の幾 何学的パラメータのみに着目した理論的な検討を実施 したが, 今後地盤の力学的パラメータを含めた検討に 加え, 地下リスクに起因する建設コスト変動に関する 検討をも実施する所存である.

謝辞 : 本研究を取りまとめるにあたり, 貴重な議論を いただいた京都大学教授小林潔司氏および，建設技術 研究所李圭太氏に感謝します.

\section{参考文献}

1) 大津宏康, 尾ノ井芳樹 : BOT事業のプロジェクト・マネ ジメントー水力発電ケースとして一, 土木学会建設マネ ジメント発表会講演概要集, pp.159-162, 2001.

2) 織田澤利守, 小林潔司 : 海外プロジェクトにおけるリス ク分担と利潤構造, 土木学会建設マネジメント発表会講 演概要集, pp.175-178, 2001.

3) Pipattanapiwong, J. and Watanabe, T.: Multi-party Risk Management Process(MRMP) for A Construction Project Financed by An International Lender, Proceeding of Construction Engineering and Management Symposium 2000 (CEMS2000), pp.85-92, 2000. 
4) 大津宏康，大西有三 : 開発途上国建設プロジェクトでの 請負者のリスク管理に関する研究, 土木学会論文集, No.707/VI-55, pp. 207-218, 2002.

5) Harris, F. and McCaffer, R.: Modern Construction Management, Blackwell Science, 2001.

6) 中央建設業審議会 : 公共工事標準請負契約約款, 改訂版, 1989.

7) FIDIC: Conditions of Contracts for Construction for Building and Engineering Works Designed by the Employer, First Edition, 1999.

8) FIDIC: Conditions of Contract for Plant and Design-Build for Electrical and Mechanical Plant, and for Building and Engineering Works, by the Contractor, First Edition, 1999.

9) FIDIC: Conditions of Contract for EPC Turnkey Projects, First Edition, 1999.

10) 草柳俊二 : 定量的分析を基盤とした国際建設プロジェク トの契約管理, 土木学会論文集, No. 609/VI-41, pp. 87-98, 1998.
11) Head, C.: Financing of Private Hydropower Projects, World Bank - Discussion Paper No. 420, The World Bank, 2000.

12）大西有三，田中誠，大沢英昭 : 不均質地盤内の地盤定数 の推定に関する基礎的研究，土木学会論文集，No.457/ III-21, pp. 51-58, 1992.

13) 大津宏康, 田中誠 : 不連続性岩盤の調査・解析と評価一 不連続性岩盤における調査・解析事例（浸透問題）（そ の 2），土と基礎，Vol.48，No.12 Ser.515, pp.61-66, 2000.

14) 山下智志 : 市場リスクの計量化と VaR, 朝倉書店, 2000.

(2002. 5. 1 受付)

\title{
A CONSIDERATION ON THE ASSESSMENT AND ALLOCATION OF GEOTECHNICAL RISK IN PFI CONSTRUCTION PROJECTS
}

\author{
Hiroyasu OHTSU, Yoshiki ONOI, Toshihiko OMOTO, Yuzo OHNISHI, \\ Satoshi NISIYAMA and Shuusaku KINOSE
}

This paper focuses on the basic concept how to rationally allocate geotechnical risk in construction projects. Firstly, risk allocation policies specified in each typical construction contract represented by FIDIC are investigated. Finally, conclusions make it obvious that both project owner and contractor principally share geotechnical risk in construction projects, and that both parties should cooperate to establish methodologies associated with the reduction of potential loss due to the geotechnical risk. 